\title{
Molecular Genotypic Diversity of Populations of Brinjal Shoot and Fruit Borer, Leucinodes Orbonalis and Development of SCAR Marker for Pesticide Resistance
}

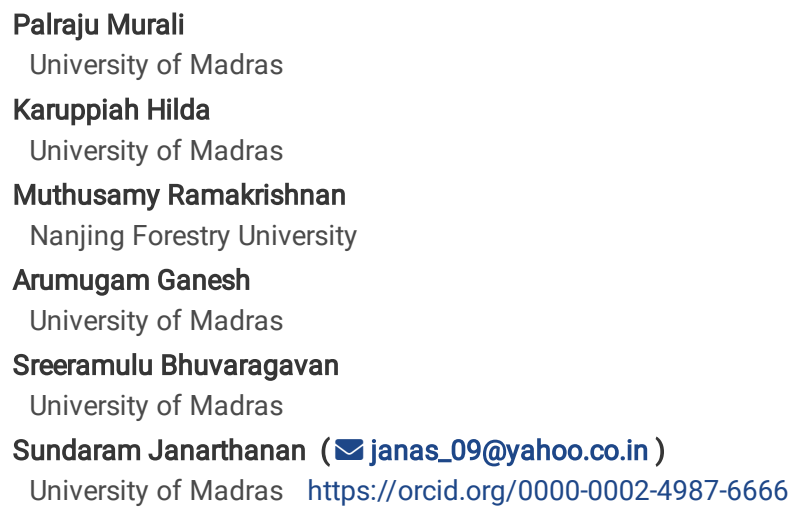

Version of Record: A version of this preprint was published at Molecular Biology Reports on October 16th, 2021. See the published version at https://doi.org/10.1007/s11033-021-06791-2. 


\section{Abstract}

The brinjal shoot and fruit borer, Leucinodes orbonalis is a destructive pest of Solanum melongena. The control of L. orbonalis with extensive application of synthetic chemical insecticides resulted in the development of resistance with known genetic heterogeneity among populations. Understanding the genetic diversity of their populations is important in developing strategies for their management. The present investigation was performed to characterize populations of $L$. orbonalis for their genetic diversity in the entire region of Tamil Nadu, South India using random amplified polymorphic DNA (RAPD) primers as a tool of the molecular marker. Among sixty random 10-mer primers, only ten primers generated reproducible and scorable banding profile. Among the ten different random primers, the primers namely OPG 7, OPG 8, OPS 2 and OPS 7 generated the highest genetic variation with over $80 \%$ genetic polymorphism. Phylogram analysis produced 18 clusters with 8 major and 10 minor clusters. Cluster analysis, statistical fitness, population structure and analysis of molecular variance confirmed the significant genetic variation among different populations. A trait specific marker obtained through RAPD was cloned, sequenced and used to develop a stable diagnostic SCAR marker for DNA fingerprinting to distinguish the populations. Amplification of this locus in the samples of 20 different populations indicated recognition of the trait for pesticide resistance in 12 populations. The results suggest that the biochemical nature of host plant varieties of this insect pest and variation in the application of different insecticides are essential contributing factors for the genotypic variations observed among populations of L. orbonalis.

\section{Introduction}

Brinjal, popularly known as eggplant (Solanum melongena L.) is a native vegetable crop of India and has been cultivated in the country for over 4000 years. It is a commercially cultivable vegetable crop among the members of family Solanaceae. India produces about $13.44 \mathrm{~m}$ MT of brinjal from an area of $0.722 \mathrm{M}$ ha with average productivity of $18.6 \mathrm{MT} / \mathrm{ha}$ (Yadav et al. 2015). This crop has been infested by a major insect pest, Leucinodes orbonalis throughout the year with a yield loss of $40-80 \%$ (Alam et al. 2003). Pest control by synthetic chemical insecticides in eventual manner promotes resistance, appearance of secondary pests, harm to non-target organisms, accumulation of chemical residues in soil and thereby leading to contaminated environment

(Alam et al. 2003; Eswara and Srinivasa 2004). The stress that is caused in this context leaves no choice to the populations of $L$. orbonalis but to adapt with the altered measures in their behavioural pattern, reproduction etc. Apparently, the regular insecticide usage in a way helped $L$. orbonalis not only to be uncontrolled but also having developed with genetic resistance via genotypic variations in their genome (Alyokhin et al. 2008). This absolutely necessitates the molecular marker-based analysis to uncover the genotypic variations happening in the species population and to frame an effective plan under insect pest management programmes (Smith and Wayne 1996; Symondson and Liddell 1996). There are barely limited numbers of works available in India on the study of genetic variation in the population of L. orbonolis using molecular markers (Karthikeyan et al. 2005; Geetharajalakshmi et al. 2006; Marimuthu et al. 2009; Ghante et al. 2013). Therefore, the present investigation was aimed to characterize populations of brinjal shoot and fruit borer, $L$. orbonalis for their genetic diversity throughout the entire region of Tamil Nadu (South India) using RAPD random primers as a tool of the molecular marker and further developing the suitable Sequence Characterized Amplified Region (SCAR) marker to identify the pesticide resistance population.

\section{Materials And Methods Insect collection}

Fifth instar larvae of L. orbonalis (Lepidoptera: Crambidae) were collected from the infested fruit and shoot of brinjal from twenty different locations (brinjal cultivation fields) of Tamil Nadu as stated in Table 1 and Fig. 1 (Population-1: Madurai; Population-2: Dindigul; Population-3: Theni; Population-4: Namakkal; Population-5: Erode; Population-6: Karur; Population-7: Salem; Population-8: Virudhunagar; Population-9: Tirunelveli; Population-10: Dharmapuri; Population11: Kanyakumari; Population-12: Villupuram; Population-13: Trichy; Population-14: Pudukottai; Population-15: Tanjore; Population-16: Ariyalur; Population17: Perambalur; Population-18: Coimbatore; Population-19: Tirupur; Population-20: Ooty). The collected fifth instar larvae were stored in 70\% ethanol and brought to the laboratory.

\section{Isolation of genomic DNA}

Larvae were dissected out to remove the entire gut and the remaining larval tissue was washed with distilled water. The genomic DNA was purified from fifth instar larvae using HiPurA ${ }^{\mathrm{TM}}$ (HiMedia Laboratories, Mumbai, India) genomic DNA purification kit. Purified genomic DNA was quantified using a spectrophotometer (Eppendorf).

\section{PCR-RAPD analysis}

PCR-RAPD analysis was carried out according to Lima et al. (2000). The amplification was performed in 20 $\mu$ l of the reaction mixture with PCR buffer (2X Master Mix-Red-Gene Technologies, Chennai, India) containing Tris- $\mathrm{HCl}$ pH 8.5, 3mM MgCl $2,0.4 \mathrm{mM}$ dNTP, 25 pM primer, 0.2 units Taq DNA polymerase, sterile water, $25 \mathrm{ng}$ genomic DNA, inert red dye and stabilizer. Initially, a total of 60 RAPD 10-mer random primers (Eurofins Genomics, Bangalore, India) were screened for selection of suitable primers for further analysis. Among the 60 primers, 10 primers were further chosen based on the production of a consistent and scorable amplification pattern in RAPD profile of L. orbonalis. The amplification reactions were performed in a thermal cycler (MyGene ${ }^{\mathrm{TM}}$ Series Peltier Thermal Cycler, LongGene MG25+, Version 3.20) programmed for an initial denaturation $\left(94^{\circ} \mathrm{C}\right.$ for $5 \mathrm{~min}$ ) followed by 35 cycles (each cycle comprised denaturation for $1 \mathrm{~min}$ at $94^{\circ} \mathrm{C}$, annealing for $1 \mathrm{~min}$ at $37^{\circ} \mathrm{C}$ and extension for $2 \mathrm{~min}$ at $72^{\circ} \mathrm{C}$ ) with a final extension of $72^{\circ} \mathrm{C}$ for $7 \mathrm{~min}$ and stored at $4^{\circ} \mathrm{C}$. The amplified PCR products were loaded on 1.5\% (w/v) agarose gel and the gel was electrophoresed at 100V for 3h using 1X tris-borate-EDTA (TBE) buffer. The gel was stained with ethidium bromide, observed under UV trans-illuminator and photographed.

Page 2/21 


\section{Genetic analysis}

The percentage of polymorphism was calculated using amplified allelic fragments showing unique multi-locus RAPD fingerprints. Polymorphic information content (PIC) was calculated with the help of PIC Calc program (Nagy et al. 2012). Most distinct bands from RAPD profile were chosen for genetic statistical analysis. The amplified fragments were scored as 1 (presence of a band) and 0 (absence of a band). The RAPD data were analyzed for similarity coefficients to find out the genotypic variation among populations using PAST version-2 software (Hammer et al. 2001). Dendrograms were constructed with bootstrap values based on the Jaccard's similarity coefficient (Real 1999).

\section{AMOVA analysis}

The genetic variance observed in RAPD data was assessed using analysis of molecular variance (AMOVA) with GenAlEx software version-6.5 (Peakall and Smouse 2012). It was used to estimate the total molecular variance observed among and within populations of $L$. orbonalis.

\section{Statistical fitness analysis}

Genetic structure, cluster analysis and cophenetic correlation coefficient analysis (CCC) were performed using UPGMA (Un-weighted Pair Group Method with Arithmetic Mean). Population distribution was assessed by principal component analysis (PCA). Principle coordinate analysis (PCO) was generated using PAST version-2 software (Hammer et al. 2001). The major substantial components to infer from PCA were determined by both Jolliffe cut-off value and broken stick model (Jolliffe 2002; Legendre and Legendre 2012). The value of accuracy of a principal component over 0.60 or less than 0.60 was considered as significant (McGarigal et al. 2013).

\section{Population structure analysis}

Population structure and gene flow analysis was carried out using 20 different populations of

L. orbonalis with a model based on clustering to subdivide genotypes into genetic subpopulations (SPs) using the software STRUCTURE v.2.3.4 (Pritchard et al. 2000). The number of SPs that existed in the samples were analyzed purely based on PCR-RAPD profiles. Each $L$. orbonalis population was considered as a member of a different subgroup (Admixture model; ALPHAPROPSD $=0.20$ ). The number of subgroups $(k)$ in the population was determined by running the programme with $\mathrm{k}$ values varying from 1 to 10 with five independent runs for each $\mathrm{k}$ value. To determine the most appropriate $\mathrm{k}$ value, Markov Chain Monte Carlo (MCMC) (Karandikar 2006) simulations were set to 100,000 and data were collected over 500,000 MCMC replications in each run. The k value was detected by employing an ad hoc statistic $\Delta K$ based on the rate of change in the log probability of data between successive $K$ values using Structure Harvester (Evanno et al. 2005).

\section{Cloning of trait specific gene fragment (SCAR marker)}

A FavorPrep ${ }^{\text {TM }}$ Gel/PCR purification kit (Favorgen, Europe) was used to excise the polymorphic band from the agarose gel. The extraction method was followed according to the manufacturer's protocol. The purified product was sequenced using the Sanger sequencing method on an ABI $3730 \mathrm{XL}$ (Applied Biosystems, USA). The pGEM ${ }^{\circledR} T$ vector system I was purchased from the Promega and the ligation of extracted polymorphic band were performed according to the manufacturer's protocol. High-Efficiency JM109 cells (non-competent) were purchased from Promega. These cells were quadrant streaked in prepared M9 + B1 plates (minimal media) to obtain a single colony. The colony is propagated for competent cell preparation using $\mathrm{CaCl}_{2}$ and stored in aliquots at $-80^{\circ} \mathrm{C}$. Luria Bertani medium (LB) plates with ampicillin, IPTG and X-gal were prepared. The transformation was performed by a heat shock of JM109 HighEfficiency competent cells mixed with ligation reaction. Transformation culture was plated onto the LB/ampicillin/IPTG/X-gal plates and screened (blue/white) for recombinant (white) colonies.

\section{Primer designing and amplification of SCAR marker in L. orbonalis population}

The plasmid DNA was isolated from the recombinant colonies. The M13 primers of transcription initiation site in pGEM ${ }^{\circledR} \mathrm{T}$ vector system I were used to amplify the vector sequence followed with trait specific gene sequence residing in isolated plasmid to identify the orientation of the gene fragment. The product was sequenced by Sanger's method (Applied Biosystems). The nucleotide sequence of the SCAR marker was then used to design a set of specific primers for amplification of SCAR marker for the detection of insecticide resistance populations of $L$. orbonalis.

\section{Results}

\section{PCR-RAPD analysis}

PCR was carried out using sixty random RAPD primers on genomic DNA samples isolated from the larvae of $L$. orbonalis collected at twenty different locations in Tamil Nadu, South India. Each genomic DNA material was a pooled population sample from four individual larvae of $L$. orbonalis. Primers that produced consistent and scorable amplified DNA fragments were then submitted to the second round of amplification. The selected ten various random primers were applied to larval DNA samples obtained from twenty different populations of

L. orbonalis for their diagnostic ability to distinguish genetic variability among samples of populations (Table 2 ). The ten random primers produced 1375

Page $3 / 21$ 
scorable bands for the pooled twenty different populations (Fig. 2). The total scorable bands were equal to 68.75 bands / population for 10 primers or 137.5 bands/primer for 20 populations. Otherwise, it was calculated as an average of 6.88 bands/population/primer. Among the ten selected random primers that produced consistent RAPD profiles, seven different primers namely, OPA 7, OPG 7, OPG 8, OPK 6, OPS 2, OPS 7 and OPS 8 produced over $70 \%$ polymorphic bands (Table 3, Fig. 3) for the 20 different populations of L. orbonalis. Within these seven random primers, OPG 7, OPG 8, OPS 2 and OPS 7 were responsible for the production of over $80 \%$ polymorphic bands. It was interesting to observe that the primer, OPS 8 revealed $100 \%$ polymorphic bands. The size of the amplified DNA fragments was ranged from $2750 \mathrm{bp}$ to $200 \mathrm{bp}$.

Genetic relationship among the amplified RAPD profiles of various populations of L. orbonalis was revealed by the Jaccard similarity coefficient values as shown in Table 4. A UPGMA based Jaccard coefficient similarity values were ranged from 0.39 to 0.72 . Of the pair-wise relationships observed among 20 different populations of $L$. orbonalis, the population collected at Karur and Dindigul districts showed a minimum similarity index of 0.39 and a maximum similarity index value of 0.72 between the populations of Karur and Salem. The dendrogram constructed based on the RAPD profiles for the 20 different populations resulted in 6 major clusters and 14 minor clusters. Most of the populations of L. orbonalis viz., Dindigul, Theni, Ooty, Perambalur, Ariyalur, Kanyakumari, Karur, Tirupur, Villupuram, Dharmapuri, Salem, Tirunelveli, Namakkal and Tanjore occurred in minor clusters while the other remaining populations of Erode, Pudukottai, Trichy, Madurai, Virudhunagar and Coimbatore were observed in the major clusters (Fig. 3). The total number of bootstrap values observed in cluster node was 19 and the values ranged from 0 to $100 \%$. Out of 19 cluster nodes, node 7 (36.8\%) showed the higher bootstrap value of $30-100 \%$ and node 12 (63.2\%) produced a lower bootstrap value of $0-16 \%$. The average bootstrap value was $20.1 \%$. However, the bootstrap value was observed as $100 \%$ in the final node of the cluster. This value showed that nodes of clusters were well supported; only internode was found to be poorly supported. Karur and Salem districts showed the highest bootstrap value of $43 \%$ followed by Theni-Dindigul and Kanyakumari-Ariyalur each with $36 \%$ and Dharmapuri-Tanjore and Villupuram-Tirupur showed each with 35\%. Remaining populations revealed lower bootstrap values (Fig. 3). It was thus confirmed based on the cluster grouping and bootstrap values that all the L. orbonalis samples (i.e., among populations) collected at 20 different locations in Tamil Nadu, India were genetically distinct populations.

\section{AMOVA analysis}

Hierarchical analysis of L. orbonalis diversity was carried out using AMOVA to know the variation that existed among and within populations. This analysis showed the degrees of freedom (df) value within the populations and among populations as 2 and 17, respectively. Sum of squared deviations (SS) value within the populations and among populations were 0.218 and 2.532 , respectively. The mean of squared deviation (MS) values within the populations and among populations were 0.109 and 0.149 , respectively. The percentage of molecular variance within the populations was less than $1 \%$ and among populations, it was above 99\%. The PhiPT, PhiPT max, Phi'PT values were $-0.043,0.851$ and -0.050 , respectively. The AMOVA analysis using RAPD data revealed genetic variation among the populations rather than within populations of

L. orbonalis.

\section{Statistical fitness analysis}

PCA and PCO analyses were applied to determine the genetic diversity among populations of $L$. orbonalis collected at different locations. In PCA, the first and third component axes exhibited a total variance of $11.8 \%$ and $8.4 \%$, respectively, and eigenvalue was 2.2 and 1.5 , respectively. Hence, based on the Euclidean similarity index, PCA was plotted with the first and third components. This showed that several populations were closely dispersed in first component axes. Significant overlap arisen mostly at third component among different populations of $L$. orbonalis which suggested that different sites in the PCA plot were straightforward to estimate the genetic diversity. To proof read the PCA, the loading analysis was implemented. In this, based on the latitude and longitude sites, the species were correlated at the third component level, which reinforced the accuracy of PCA. PCA scatter diagram showed the Jolliffe cut-off value of 0.10267 and the first 8 principal components (PCs) with eigen values greater than (2.22296 to 1.04826) the cut-off value (Fig. 4). PCs related to the covariance matrix had eigen values bigger than the average (all the eigen values) and confirmed those were significant. PCO was produced according to the Euclidean similarity index; the first and third coordinate axes accounted for $11.8 \%$ and $8.4 \%$ total variance with eigen value of 356.6 (Fig. 5). PCO plot was made using the first and third coordinate and the Tirupur, Ariyalur, Villupuram and Kanyakumari districts were in third coordinate.

The genetic distance matrix was also studied using nMDS approach based on three dimensions. The stress values for the three axes were 0.2431 (axes $1=$ 0.4989 , axes $2=0.06648$, axes $3=0.02801$ ). The nMDS three-dimensional scatter plot result was figured using the second and third coordinate based on the Euclidean similarity index (Fig. 6). The position of the L. orbonalis population was found to be consistent with the grouping pattern of the UPGMA clustering, and the $L$. orbonalis population adaptations on the three-dimensional nMDS plot were linked with the latitude and longitude site of the species collection on the world map. The nMDS Shephard's plot produced similar value in both obtained rank and target rank with a range from 20 to 180 which confirmed that the nMDS plot represented an excellent fit to the evolutionary distance matrix between collection sites. In histogram investigation, the frequency of similarity value was also 0.1 to 1.0 which was corresponded to Jaccard's similarity coefficients value. The CCC value was 0.7 which identified that the clustering result was very acceptable for the genetic similarity matrix calculation.

\section{Population structure analysis}

The structure analysis produced that 20 populations were broadly divided into three subpopulations (SPs) as SP1, SP2 and SP3. The molecular variance among the SPs showed different confirmation for gene flow between SPs. An analysis of the precise population structure (K), ( $\mathrm{K}$ value 1 to 10 with 5 runs for each $\mathrm{K}$ value independently) was analyzed and the $\mathrm{LnP}(\mathrm{D})$ value was used for all the 20 samples. Structure analysis showed maximum $\mathrm{DK}$ value, $\mathrm{K}=3$. These three SPs also confirmed that Jaccard's similarity coefficient analysis. Theni, Karur, Dindigul, Salem, Madurai, Tirunelveli, Namakkal and Erode district species 
were placed in SP1. Pudukottai, Dharmapuri, Tanjore, Virudhunagar and Villupuram district species were placed in SP2. Similarly, Ariyalur, Kanyakumari, Ooty, Coimbatore, Perambalur and Tirupur district species were placed in SP3. The results of the structure produced that all the three SPs had an admixture of alleles and only one pure species (Theni) was observed. Karur, Dindigul, Salem, Madurai, Tirunelveli, Namakkal, Erode, Dharmapuri, Ariyalur, Kanyakumari, Ooty and Coimbatore populations contained $85-98 \%$ pure alleles. The AMOVA analysis also produced a consistent relationship, representing high intrapopulation variation, which confirmed that the SPs had a strong genetic structure (Fig. 7).

\section{Development of SCAR marker based on trait specific locus}

Based on the higher level of polymorphic profile generated by the random primer OPS 08 , a trait specific locus representing insecticide resistant gene fragment was identified. This trait specific polymorphic band with a size of approximately $0.5 \mathrm{~kb}$ was purified from the agarose gel and subjected to the electrophoresis to confirm its purity (Fig. 8) for its development in to a SCAR marker. It was then used as insert DNA for cloning into the pGEM ${ }^{\circledR} T$ vector system for nucleotide sequencing and trait specific designing of primers. The trait specific locus representing insecticide resistant gene (SCAR marker) was ligated in the lacZ region of pGEM ${ }^{\circledR} T$ vector system-I (with a vector size of $3 \mathrm{~kb}$ ). The ligation reactions were transformed into the competent cells of JM109 strain. Both recombinant and non-recombinant colonies were observed on the LB plates in presence of ampicillin incubated overnight at $37^{\circ} \mathrm{C}$ (Fig. 9). The isolated plasmid was then quantified using NanoDrop UV-Vis Spectrophotometer (Eppendorf, USA). The quantity of plasmid from the recombinant colony was $893 \mu \mathrm{g} / \mathrm{ml}$ with the purity of 1.06 at the absorbance of $260 / 280 \mathrm{~nm}$. The identified SCAR marker as a diagnostic tool for insecticide resistance subjected to sequencing resulted in a product size of $402 \mathrm{bp}$ (Fig. 10). Specific primers (18 bp - sense primer sequence: 5' TAATGTTGCTGTGATACG 3 ' and a 20 bp - antisense primer sequence:

5' GAATATGTCTTCCTGTTGAT 3') were subjected for amplification of SCAR marker-based detection of insecticide resistance using various genomic DNA isolated from twenty different populations of $L$. orbonalis. The PCR results indicated that an amplified product with an expected size of approximately $400 \mathrm{bp}$ in

L. orbonalis populations collected at Dindigal, Theni, Namakkal, Karur, Salem, Tirunelveli, Dharmapuri, Kanyakumari, Villupuram, Tanjore, Coimbatore and Tirupur by the diagnostic SCAR marker (Fig. 11). It was found that all these 12 populations were resistant to insecticides through the trait diagnosed by the development of SCAR marker with successful employment of this tool among populations.

\section{Discussion}

Determining the genetic variability is one of the important tools used in designing pest control practices of an integrated pest management programme. Variation at the genetic level seen largely in insect pest species are through their interaction with environmental factors by the natural selection process and this offers the basis for evolutionary change (Marimuthu et al. 2009). Gene flow, genetic drift and natural selection interact in equilibrium to produce genetic variations among populations (Futuyma and Peterson 1985). Though natural selection does not reflect directly on phenotype, it is a major factor causing a genetic differentiation at the molecular level. Random amplified polymorphic DNA (RAPD) is an efficient assay system useful for the study of genetic variability (Beeman and Brown 1999; Infante-Malachias et al. 1999; Bas et al. 2000; Gill et al. 2006). The polymorphic genomic DNA provided by RAPD markers allows rapid identification and isolation of chromosome-specific DNA fragments, its deletion or addition in the genetic pool of large chromosomal segment (Jain et al. 2010). In the present study, genetic diversity among the populations of brinjal shoot and fruit borer, L. orbonalis in Tamil Nadu, India was demonstrated using RAPD random primers as molecular markers. This work was formed because of the inadequate research works reported previously on the genetic diversity of brinjal pest, $L$. orbonalis. Genetic variations based on RAPD analysis was reported only in five different populations of $L$. orbonalis with a restricted area of study (Karthikeyan et al. 2005). Based on the intensity of brinjal growing farms such as high, moderate and low-intensity cultivations, populations of $L$. orbonalis were collected at 10 different regions, revealed intraspecific variations based on random primers (Geetharajalakshmi et al. 2006). Similar such work was carried out by Marimuthu et al. (2009), reporting only two major clusters with no variations among populations using RAPD assays. Detection of genetic variations in the populations of L. orbonalis in north Karnataka was screened in ten locations with varying degrees of genetic similarity (Ghante et al. 2013). This prompted to attempt to reveal the variation among the populations of $L$. orbonalis from twenty different locations on the entire region of the state of Tamil Nadu.

Populations of the brinjal shoot and fruit borer, L. orbonalis collected from different brinjal growing areas in our study throughout Tamil Nadu revealed genetic variations. Of the ten different random primers used, the primers namely OPG 7, OPG 8, OPS 2 and OPS 7 generated highest genetic variation with over $80 \%$ polymorphism among the populations of $L$. orbonalis in the present investigation. It was also interesting to observe that the primer, OPS 8 , revealed $100 \%$ polymorphism. A UPGMA based similarity coefficient values were ranged from 0.39 to 0.72 . The dendrogram constructed based on the RAPD profiles for the 20 different populations resulted in 6 major clusters and 14 minor clusters. Based on the cluster grouping and bootstrap values, it was confirmed that all $L$. orbonalis samples collected at 20 different places of Tamil Nadu, India were genetically distinct populations. This could be due to different cropping pattern, varieties of brinjal cultivation, application of insecticides and their types to manage this insect pest. During collection, it was observed that at least a dozen varieties of brinjal cultivated at different locations. Studies on the biochemical basis of resistance to L. orbonalis and their correlation with the shoot and fruit borer infestation in selected brinjal genotypes showed that less susceptible genotypes had the higher amount of polyphenol oxidase, phenylalanine ammonium lyase and lignin and a lower amount of reducing sugar (Khorsheduzzaman et al. 2010). This biochemical basis of resistance in plants could definitely been a contributing factor for the genetic variations observed among populations of $L$. orbonalis. A field study conducted for screening the 52 cultivable brinjal genotypes from the 14 states of India concluded with the resistance towards $L$. orbonalis only by four genotypes where rest were categorized as tolerant and highly susceptible (Rameash et al. 2015). An extensive report on socio-economic assessment of brinjal cultivation in Tamil Nadu with context to insect resistance stated $32 \%$ percent (higher) of major constraints in production was by insect damage (Ashok et al. 2019).

Brinjal growers mostly depend on insecticides to battle this huge damage-causing insect pest. Reports reveal that synthetic chemical insecticides dominate in the control of L. orbonalis (Latif et al. 2010). In India, over 95\% of farmers apply insecticides more than 40 sprays per season with two or three times a week (Alam et al. 2006). A survey also revealed that farmers exclusively rely on the application of insecticides in managing this pest. The insecticides used

Page 5/21 
mostly are organophosphates, carbamates and synthetic pyrethroids (Alam et al. 2003). Brief information of insecticides used in the collected sample sites against $L$. orbonalis infesting brinjal crops is given in Table. 5 . There is also variation in the application of these insecticides from field to field and the efficacy of the type of insecticides used against L. orbonalis in a particular location might have different levels of toxic action (Latif et al. 2010). In our present study, among 20 populations of $L$. orbonalis assayed for genetic characterization, the population collected at Karur and Dindigul districts showed a minimum similarity index of 0.39 . But at the same time, a maximum similarity index value of 0.72 was recorded in the populations of Karur and Salem. The distance between Karur to Dindigul and Karur to Salem is only around 90 kilometers and with this same distance, we could able to observe both minimum and maximum similarity index. Under such circumstances, it could be reasonable to believe that the variation in the application of nature of insecticides brought about the enormous gap in similarity indices.

The AMOVA analysis using RAPD data showed that the genetic variation was observed among the populations rather than within populations of $L$. orbonalis. The population structure analysis revealed the formation of three subpopulations as SP1, SP2 and SP3. The molecular variance among the SPs showed different confirmation for gene flow between SPs. A population may be considered as a single unit. However, in many species and situations, populations are separated into smaller units. Such separation might be either due to ecological factors where habitats are not continuous or behavioural features with the relocation of populations consciously or unconsciously. In such a situation, the genetic links among its parts may vary, depending on the actual amount of gene flow taking place. There are at least three reasons with which a population is considered structured. They are (a) occurrence of genetic drift in several of its subpopulations, (b) no uniform migration throughout the population or (c) the process of mating is not random throughout the population

(De Vicente et al. 2004). Consequently, the structure of a population influences the extent of genetic variation and its distribution patterns. Our study with twenty different populations subdivided or separated into three major subpopulations could definitely due to one or more of the reasons explained here. Our previous study has verified the phylogeographical relationships among the insect pest, $L$. orbonalis to validate the population genetic structure based on mitochondrial COI gene sequences (Palraju et al. 2018). Exploring further with RAPD markers could essentially set a base for deriving the sequence characterized amplified region (SCAR) marker to identify the resistance traits. In that context, generation of molecular or trait specific characters using different populations of a species or at various stages of taxonomy could be used as diagnostic tools after screening with synthetic short oligonucleotide primers. In order to establish genetic relationships, it is either identified as polymorphic amplified fragments between species within the genus or constant amplified fragments diagnostic for a genus. Fragments that are amplified at polymorphic loci at the species level could be used to recognize members of a given species if that fragment is constant among all members of that species in order to ascertain trait-specific character (Hadrys et al. 1992). Use of molecular markers in mapping experiments has identified quantitative trait loci that determine the insecticide resistance phenotypes in insects (Ranson et al. 2000). Likewise, using random amplified DNA with RAPD markers, genetic loci have been mapped in lesser grain borer, Rhyzoperthadominica that determines high-level resistance to phosphine (Schlipalius et al. 2002). Also, conversion of RAPD markers into SCAR markers has been reported and applied to improve the low reproducibility of RAPD (Paran and Michelmore 1993). SCAR is a genomic fragment localized in a single genetically defined locus that can be amplified by PCR using a pair of specific primers. It is low in sensitivity to PCR reaction conditions, allowing for an excellent reliability among various laboratory conditions (Fernandez et al. 2003). This study dealing with various populations of L. orbonalis suggests the possibility of exploring co-dominant markers through transfer of RAPD amplified fragments into SCAR marker. A trait specific marker obtained through RAPD in L. orbonalis was developed as a stable diagnostic SCAR marker for DNA fingerprinting to distinguish the populations of brinjal shoot and fruit borer collected at different geographical locations in Tamil Nadu, South India for insecticide resistance. The results have shown that the developed SCAR marker could be highly useful as a trait specific identification tool, particularly for distinguishing insecticide resistant populations in L. orbonalis.

\section{Declarations}

\section{Funding}

The first author gratefully acknowledged University Grants Commission (UGC), New Delhi, India for the award of Teacher Fellowship under Faculty Development Programme (TNMK014/2014-2015).

\section{Conflicts of interest:}

The authors declare that they have no conflict of interest

\section{Availability of data and material:}

Not applicable

\section{Code availability:}

Not applicable

\section{Authors' contributions:}

All authors have contributed equally 


\section{Ethics approval:}

Not applicable

\section{Consent to participate:}

There were no humans participants in the study

\section{Consent for publication:}

Authors can provide the signed approval upon publisher's request

\section{CRediT authorship contribution statement}

Palraju Murali: Conceptualization, Methodology, Software, Validation, Formal analysis, Investigation, Data curation, Writing - original draft, Visualization, Funding acquisition.

Karuppiah Hilda: Methodology, Software, Validation, Formal analysis, Investigation, Data curation, Writing - review \& editing, Visualization.

Muthusamy Ramakrishnan: Conceptualization, Methodology, Software, Formal analysis, Data curation, Writing - review \& editing.

Arumugam Ganesh: Methodology, Software, Formal analysis, Data curation.

Sreeramulu Bhuvaragavan: Investigation, Data curation, Writing - review \& editing.

Sundaram Janarthanan: Resources, Writing - review \& editing, Supervision, Project administration, Funding acquisition.

\section{References}

1. Alam SN, Hossain MI, Rouf FMA, Jhala RC, Patel MG, Rath LK, Sengupta A, Baral K, Shylesha AN, Satpathy S, Shivalingaswamy TM (2006) Implementation and promotion of an IPM strategy for control of eggplant fruit and shoot borer in South Asia. Technical Bulletin no. 36, AVRDC publication no. 06-672, AVRDC, The World Vegetable Center, Shanhua, Taiwan, pp 74

2. Alam SN, Rashid MA, Rouf FMA, Jhala RC, Patel JR, Satpathy S, Shivalingaswamy TM, Rai S, Wahundeniya I, Cork A, Ammaranan C (2003) Development of an integrated pest management strategy for eggplant fruit and shoot borer in South Asia. Technical Bulletin no. 28, AVRDC publication no. 03-548, AVRDC-World Vegetable Center, Shanhua, Taiwan, pp 56

3. Alyokhin A, Baker M, Mota-Sanchez D, Dively G, Grafius E (2008) Colorado potato beetle resistance to insecticides. Am J Potato Res 85:395-413. https://doi.org/10.1007/s12230-008-9052-0

4. Ashok KR, Chinnadurai M, Raj SV, Sanjeevikumar A (2019) Socio-economic Assessment of LMOs: An ex ante analysis of insect resistance and herbicide tolerance in maize and brinjal in Tamil Nadu. In: Socio-economic impact assessment of genetically modified crops, Springer, Singapore, pp 101-120

5. Bas B, Dalkilic Z, Peever TL, Nigg HN, Simpson SE, Gmitter FG, Adair RC (2000) Genetic relationships among Florida Diaprepes abbreviatus (Coleoptera: Curculionidae) populations. Ann Entomol Soc Am 93: 459-467. https://doi.org/10.1603/0013-8746(2000)093[0459:GRAFDA]2.0.C0;2

6. Beeman RW, Brown SJ (1999) RAPD-based genetic linkage maps of Tribolium castaneum. Genetics 153:333-8. https://doi.org/10.1093/genetics/153.1.333

7. De Vicente MC, Lopez C, Fulton T (2004) Genetic diversity analysis with molecular marker data: learning module. Int Plant Genet Resour Inst

8. Eswara R, Srinivasa SG (2004) Management of shoot and fruit borer, Leucinodes orbonalis (Guen.) in brinjal using botanicals/oils. Pestology $28: 50-52$.

9. Evanno G, Regnaut S, Goudet J (2005) Detecting the number of clusters of individuals using the software STRUCTURE: A simulation study. Mol Ecol 14:2611-2620. https://doi.org/10.1111/j.1365-294X.2005.02553.x

10. Fernandez S, Costa AC, Katsuyama AM, Madeira AMBN, Gruber A (2003) A survey of the inter- and intraspecific RAPD markers of Eimeria spp. of the domestic fowl and the development of reliable diagnostic tools. Parasitol Res 89:437-445. https://doi.org/10.1007/s00436-002-0785-2

11. Futuyma DJ, Peterson SC (1985) Genetic variation in the use of resources by insects. Annu Rev Entomol 30: 217-238. https://doi.org/10.1146/annurev.en.30.010185.001245

12. Geetharajalakshmi S, Subramanian S, Shanmugasundaram PS, Mohankumar S (2006) Molecular analysis of Leucinodes orbonalis Guen. populations within Tamil Nadu using lepidopteran specific random primers. Pest Manag Hortic Ecosyst 12:29-36.

13. Ghante VN, Kumar LR, Chowdary LR, Poornima R, Kisan B, Bheemanna M, Arunkumar H (2013) Detection of genetic variation in brinjal shoot and fruit borer (Leucinodes orbonalis G.) populations using RAPD markers. BIOINFOLET-A Q. J Life Sci 10:1208-1210.

14. Gill TK, Kumri S, Sharma VL, Badran AA, Kumari M, Sobit RC (2006) Genetic Variation in polymorphic males of Callosobruchus maculatus (Coleoptera: Bruchidae) by RAPD-PCR. Cytologia (Tokyo) 71:57-62. https://doi.org/10.1508/cytologia.71.57

15. Hadrys H, Balick M, Schierwater B (1992) Applications of random amplified polymorphic DNA (RAPD) in molecular ecology. Mol Ecol 1:55-63. https://doi.org/10.1111/j.1365-294X.1992.tb00155.x 
16. Hammer $\emptyset$, Harper DA, Ryan PD (2001) PAST: Paleontological statistics software package for education and data analysis. Palaeontol Electron 4:19. https://doi.org/10.1016/j.bcp.2008.05.025

17. Infante-Malachias ME, Yotoko KSC, Espin A (1999) Random amplified polymorphic DNA of screwworm fly populations (Diptera: Calliphoridae) from Southeastern Brazil and Northern Argentina. Genome 42:772-779. https://doi.org/10.1139/gen-42-4-772

18. Jain SK, Neekhra B, Pandey D, Jain K (2010) RAPD marker system in insect study: A review. Indian J Biotechnol 9:7-12. http://nopr.niscair.res.in/handle/123456789/7117

19. Jolliffe IT (2002) Principal components as a small number of interpretable variables: some examples. In: Principal component analysis, Springer series in statistics, Springer, New York, pp 63-77.

20. Karandikar RL (2006) On the markov chain monte carlo (MCMC) method. Sadhana 31:81-104. https://doi.org/10.1007/BF02719775

21. Karthikeyan KAM, Vijayakumar I, Murali P, Suresh P, Janarthanan S (2005) Detection of genetic polymorphism in the populations of brinjal shoot and fruit borer, Leucinodes orbonalis (Guenee). Indian J Exp Biol 43:548-551. http://nopr.niscair.res.in/handle/123456789/23158

22. Khorsheduzzaman KM, Alam MZ, Rahman MM, Mian MK, Mian MI (2010) Biochemical basis of resistance in eggplant (Solanum melongena L.) to Leucinodes orbonalis Guenée and their correlation with shoot and fruit infestion. Bangladesh J Agric Res 35:149-155. https://doi.org/10.3329/bjar.v35i1.5876

23. Latif MA, Rahman MM, Alam MZ (2010) Efficacy of nine insecticides against shoot and fruit borer, Leucinodes orbonalis Guenee (Lepidoptera: Pyralidae) in eggplant. J Pest Sci 83:391-397. https://doi.org/10.1007/s10340-010-0309-2

24. Legendre P, Legendre LFJ (2012) Numerical ecology, 3rd edn. Elsevier, Oxford, UK.

25. Lima LHC, Návia D, Inglis PW, de Oliveira MRV (2000) Survey of Bemisia tabaci (Gennadius) (Hemiptera: Aleyrodidae) biotypes in Brazil using RAPD markers. Genet Mol Biol 23:781-785. https://doi.org/10.1590/S1415-47572000000400012

26. Marimuthu M, Perumal Y, Salim AP, Sharma G (2009) Genetic similarity of eggplant shoot and fruit borer, Leucinodes orbonalis, populations. DNA Cell Biol 28:599-603. https://doi.org/10.1089/dna.2009.0920

27. McGarigal K, Cushman SA, Stafford S (2013) Multivariate statistics for wildlife and ecology research, Springer Science \& Business Media, Springer-Verlag, New York.

28. Nagy S, Poczai P, Cernák I, Gorji AM, Hegedús G, Taller J (2012) PICcalc: An online program to calculate polymorphic information content for molecular genetic studies. Biochem Genet 50:670-672. https://doi.org/10.1007/s10528-012-9509-1

29. Palraju M, Paulchamy R, Sundaram J (2018) Population genetic structure and molecular diversity of Leucinodes orbonalis based on mitochondrial COI gene sequences. Mitochondrial DNA A 29:1231-1239. https://doi.org/10.1080/24701394.2018.1436169

30. Paran I, Michelmore RW (1993) Development of reliable PCR-base markers linked to downy mildew resistance genes in lettuce. Theor Appl Genet 85:985993. https://doi.org/10.1007/BF00215038

31. Peakall R, Smouse PE (2012) GenALEx 6.5: Genetic analysis in Excel. Population genetic software for teaching and research-an update. Bioinformatics 28:2537-2539. https://doi.org/10.1093/bioinformatics/bts460

32. Pritchard JK, Stephens M, Donnelly P (2000) Inference of population structure using multilocus genotype data. Genetics 155, $945-959$. https://doi.org/10.1111/j.1471-8286.2007.01758.x.

33. Rameash K, Sivaraj N, Babu BS, Chakrabarty SK (2015) Screening brinjal genotypes for resistance to shoot and fruit borer, Leucinodes orbonalis and analysing the geographic divergence of resistance through divagis. Bioscan 10:923-928.

34. Ranson H, Jensen B, Wang X, Prapanthadara L, Hemingway J, Collin FH (2000) Genetic mapping of two loci affecting DDT resistance in the malaria vector Anopheles gambiae. Insect Mol Biol 9:499-507. https://doi.org/10.1046/j.1365-2583.2000.00214.X

35. Real R (1999) Tables of significant values of Jaccard's index of similarity. Misc Zool 22:29-40.

36. Schlipalius DI, Cheng Q, Reilly PE, Collins PJ, Ebert PR (2002) Genetic linkage analysis of the lesser grain borer Rhyzopertha dominica identifies two loci that confer high-level resistance to the fumigant phosphine. Genetics 161:773-782.

37. Smith TB, Wayne RK (1996) Molecular genetic approaches in conservation, Oxford University Press, New York.

38. Symondson WOC, Liddell JE (1996) A species-specific monoclonal antibody system for detecting the remains of field slugs, Deroceras reticulatum (Muller) (Mollusca: Pulmonata), in carabid beetles (Coleoptera: Carabidae). Biocontrol Sci Technol 6:91-100.

https://doi.org/10.1080/09583159650039557

39. Yadav DK, Singh NN, Mishra VK, Singh SK (2015) Bioefficacy of certain newer insecticides against brinjal shoot and fruit borer, (Leucinodes orbonalis Guen.). J Entomol Res 39:25-30.

\section{Tables}

\section{Table 1}

Collection sites of the larval populations of L. orbonalis 


\begin{tabular}{|c|c|c|}
\hline S. No. & Districts & Abbreviation \\
\hline 1. & Madurai & MDU \\
\hline 2. & Dindigul & DGL \\
\hline 3. & Theni & $\mathrm{TNI}$ \\
\hline 4. & Namakkal & NKL \\
\hline 5. & Erode & ERO \\
\hline 6. & Karur & KRR \\
\hline 7. & Salem & SLM \\
\hline 8. & Virudhunagar & VHN \\
\hline 9. & Tirunelveli & TVL \\
\hline 10. & Dharmapuri & DMI \\
\hline 11. & Kanyakumari & KKR \\
\hline 12. & Villupuram & VPM \\
\hline 13. & Trichy & TRY \\
\hline 14. & Pudukottai & PKI \\
\hline 15. & Tanjore & TNJ \\
\hline 16. & Ariyalur & ALR \\
\hline 17. & Perambalur & PMR \\
\hline 18. & Coimbatore & CBE \\
\hline 19. & Tirupur & TRR \\
\hline 20. & Ooty & OTY \\
\hline
\end{tabular}

Table 2

List of RAPD primers used for initial screening of various populations of brinjal shoot and fruit borer, L. orbonalis

\begin{tabular}{|lllllll|}
\hline S. No & OPA & OPG & OPJ & OPK & & OPS \\
\hline 1. & OPA-01 & OPG-01 & OPJ-01 & OPK-01 & OPK-11 & OPS-01 \\
\hline 2. & OPA-02 & OPG-02 & OPJ-02 & OPK-02 & OPK-12 & OPS-02 \\
\hline 3. & OPA-03 & OPG-03 & OPJ-03 & OPK-03 & OPK-13 & OPS-03 \\
\hline 4. & OPA-04 & OPG-04 & OPJ-04 & OPK-04 & OPK-14 & OPS-04 \\
\hline 5. & OPA-05 & OPG-05 & OPJ-05 & OPK-05 & OPK-15 & OPS-05 \\
\hline 6. & OPA-06 & OPG-06 & OPJ-06 & OPK-06 & OPK-16 & OPS-06 \\
\hline 7. & OPA-07 & OPG-07 & OPJ-07 & OPK-07 & OPK-17 & OPS-07 \\
\hline 8. & OPA-08 & OPG-08 & OPJ-08 & OPK-08 & OPK-18 & OPS-08 \\
\hline 9. & OPA-09 & OPG-09 & OPJ-09 & OPK-09 & OPK-19 & OPS-09 \\
\hline 10 & OPA-10 & OPG-10 & OPJ-10 & OPK-10 & OPK-20 & OPS-10 \\
\hline \multicolumn{7}{r}{ Primers marked with bold letters produced consistent and scorable banding profile in PCR-RAPD } \\
\hline
\end{tabular}

Table 3

Total number of bands, number of monomorphic and polymorphic PCR-RAPD fragments and their percentages generated by selected random primers among various populations of

L. orbonalis collected at different locations in Tamil Nadu, South India 


\begin{tabular}{|c|c|c|c|c|c|c|}
\hline \multirow[t]{2}{*}{ S. no. } & \multirow[t]{2}{*}{ Selected primers } & \multirow[t]{2}{*}{ Total no. of bands } & \multicolumn{2}{|c|}{ Monomorphic } & \multicolumn{2}{|c|}{ Polymorphic } \\
\hline & & & Bands & $\%$ & Bands & $\%$ \\
\hline 1 & OPA 1 & 161 & 100 & 62.11 & 61 & 37.88 \\
\hline 2 & OPA 7* & 143 & 40 & 27.97 & 103 & 72.02 \\
\hline 3 & OPA 8 & 125 & 40 & 32.00 & 85 & 68.00 \\
\hline 4 & OPG 7* & 151 & 20 & 13.24 & 131 & 86.75 \\
\hline 5 & OPG 8* & 151 & 40 & 13.24 & 131 & 86.75 \\
\hline 6 & OPK 6* & 91 & 20 & 21.97 & 71 & 78.02 \\
\hline 7 & OPS 2* & 115 & 20 & 17.39 & 95 & 82.60 \\
\hline 8 & OPS 3 & 181 & 100 & 55.24 & 81 & 44.75 \\
\hline 9 & OPS 7* & 140 & 20 & 14.28 & 120 & 85.71 \\
\hline 10 & OPS $8 *$ & 117 & 00 & 00.00 & 117 & 100 \\
\hline
\end{tabular}

Table 4

Jaccard's similarity coefficient showing genetic relationship among the populations of $L$. orbonalis from different locations in Tamil Nadu

\begin{tabular}{|c|c|c|c|c|c|c|c|c|c|c|c|c|c|c|c|c|c|c|c|}
\hline Districts & MDU & DGL & TNI & NKL & ERO & KRR & SLM & VHN & TVL & DMI & KKR & VPM & TRY & PKI & TNJ & ALR & PMR & CBE & TF \\
\hline MDU & 1.00 & & & & & & & & & & & & & & & & & & \\
\hline DGL & 0.51 & 1.00 & & & & & & & & & & & & & & & & & \\
\hline TNI & 0.58 & 0.56 & 1.00 & & & & & & & & & & & & & & & & \\
\hline NKL & 0.65 & 0.54 & 0.58 & 1.00 & & & & & & & & & & & & & & & \\
\hline ERO & 0.57 & 0.51 & 0.56 & 0.55 & 1.00 & & & & & & & & & & & & & & \\
\hline KRR & 0.65 & 0.51 & 0.54 & 0.65 & 0.65 & 1.00 & & & & & & & & & & & & & \\
\hline SLM & 0.66 & 0.49 & 0.54 & 0.68 & 0.57 & 0.72 & 1.00 & & & & & & & & & & & & \\
\hline VHN & 0.55 & 0.47 & 0.56 & 0.58 & 0.51 & 0.57 & 0.54 & 1.00 & & & & & & & & & & & \\
\hline TVL & 0.57 & 0.52 & 0.63 & 0.65 & 0.60 & 0.61 & 0.64 & 0.63 & 1.00 & & & & & & & & & & \\
\hline DMI & 0.58 & 0.47 & 0.50 & 0.60 & 0.53 & 0.62 & 0.59 & 0.66 & 0.57 & 1.00 & & & & & & & & & \\
\hline KKR & 0.55 & 0.46 & 0.42 & 0.57 & 0.52 & 0.54 & 0.55 & 0.61 & 0.59 & 0.54 & 1.00 & & & & & & & & \\
\hline VPM & 0.61 & 0.45 & 0.44 & 0.61 & 0.54 & 0.61 & 0.60 & 0.59 & 0.58 & 0.58 & 0.60 & 1.00 & & & & & & & \\
\hline TRY & 0.56 & 0.52 & 0.58 & 0.62 & 0.67 & 0.70 & 0.67 & 0.61 & 0.66 & 0.59 & 0.60 & 0.64 & 1.00 & & & & & & \\
\hline PKI & 0.59 & 0.50 & 0.53 & 0.63 & 0.60 & 0.61 & 0.68 & 0.63 & 0.64 & 0.59 & 0.62 & 0.65 & 0.66 & 1.00 & & & & & \\
\hline TNJ & 0.55 & 0.45 & 0.52 & 0.66 & 0.59 & 0.62 & 0.63 & 0.58 & 0.57 & 0.68 & 0.55 & 0.60 & 0.65 & 0.66 & 1.00 & & & & \\
\hline ALR & 0.62 & 0.47 & 0.45 & 0.56 & 0.56 & 0.55 & 0.54 & 0.54 & 0.57 & 0.57 & 0.65 & 0.60 & 0.67 & 0.57 & 0.56 & 1.00 & & & \\
\hline PMR & 0.49 & 0.50 & 0.48 & 0.54 & 0.58 & 0.53 & 0.55 & 0.57 & 0.57 & 0.57 & 0.56 & 0.56 & 0.63 & 0.57 & 0.63 & 0.62 & 1.00 & & \\
\hline CBE & 0.53 & 0.44 & 0.50 & 0.53 & 0.55 & 0.59 & 0.58 & 0.55 & 0.57 & 0.53 & 0.55 & 0.54 & 0.64 & 0.54 & 0.56 & 0.56 & 0.56 & 1.00 & \\
\hline TRR & 0.53 & 0.39 & 0.40 & 0.52 & 0.52 & 0.56 & 0.57 & 0.53 & 0.49 & 0.57 & 0.51 & 0.63 & 0.60 & 0.53 & 0.60 & 0.55 & 0.53 & 0.53 & 1.1 \\
\hline OTY & 0.59 & 0.47 & 0.46 & 0.59 & 0.51 & 0.57 & 0.55 & 0.57 & 0.52 & 0.53 & 0.55 & 0.52 & 0.59 & 0.56 & 0.59 & 0.60 & 0.60 & 0.59 & 0. \\
\hline
\end{tabular}

Table 5

Details of insecticides used in the fields of brinjal against the larval infestation of shoot and fruit borer, Leucinodes orbonalis 


\begin{tabular}{|c|c|c|c|c|}
\hline Districts & Common name ${ }^{a}$ & Trade name & Manufacturer & Dose \\
\hline 1. Madurai & Carbosulfan & Marshal 25 & FMC Corporation & $50 \mathrm{ml} /$ acre \\
\hline 2. Dindigul & Deltamethrin & Deniel EC & Greenland Crop Sciences & $50 \mathrm{ml} /$ acre \\
\hline 3. Thenib & Phyrethroids & Flame & Tatva Crop Science & $70 \mathrm{ml} /$ acre \\
\hline 4. Namakkal & Fenvalerate & Fantom 20C & Chemet Chemicals Ltd. & $60 \mathrm{ml} /$ acre \\
\hline 5. Erode & Fenvalerate & Fantom 20C & Chemet Chemicals Ltd. & $60 \mathrm{ml} /$ acre \\
\hline 6. Karur ${ }^{b}$ & Spinosad & Tracer 240SC & Dow Agrosciences & $60 \mathrm{ml} /$ acre \\
\hline 7. Salem & Chlorantraneiliprole & Coragen 20SC & Dupont & $50 \mathrm{ml} /$ acre \\
\hline 8. Virudhunagar & Deltamethrin & Deniel EC & Greenland Crop Sciences & $50 \mathrm{ml} /$ acre \\
\hline 9. Tirunelveli ${ }^{b}$ & Chlorantraneiliprole & Coragen 20SC & Dow Agro Sciences & $60 \mathrm{ml} /$ acre \\
\hline 10. Dharmapuri & Flubendiamide & Belt 48SC & Bayer Crop Science & $50 \mathrm{ml} /$ acre \\
\hline 11. Kanyakumari & Triazophos & Parashute & Paramount Pesticide Ltd. & $50 \mathrm{ml} /$ acre \\
\hline 12. Villupuram & Cybermethrin & Ammo & FMC Corporation & $50 \mathrm{ml} /$ acre \\
\hline 13. Trichy & Spinosad & Tracer 240SC & Dow Agrosciences & $60 \mathrm{ml} /$ acre \\
\hline 14. Pudukottai & Triazophos & Parashute & Paramount Pesticide Ltd. & $50 \mathrm{ml} /$ acre \\
\hline 15. Tanjore & Chlorantraneiliprole & Coragen 20SC & Dupont & $50 \mathrm{ml} /$ acre \\
\hline 16. Ariyalur & Chlorantraneiliprole & Coragen 20SC & Dupont & $50 \mathrm{ml} /$ acre \\
\hline 17. Perambalur & Emamectin benzoate & Timer 1.9EC & HebbeiVian & $200 \mathrm{ml} /$ acre \\
\hline 18. Coimbatore & Malathion & Shrithion & Sri Ram Agro Chemicals & $140 \mathrm{ml} /$ acre \\
\hline 19. Tirupur & Fenvalerate & Fantom 20C & Chemet Chemicals Ltd. & $60 \mathrm{ml} /$ acre \\
\hline 20. Ooty & Deltamethrin & Deniel EC & Greenland Crop Sciences & $50 \mathrm{ml} /$ acre \\
\hline
\end{tabular}

${ }^{a}$ Maximum use of insecticide type among various synthetic chemicals used against the infestation of $L$. orbonalis ${ }^{b}$ Brinjal fields observed with higher incidence of larval infestation despite application of synthetic insecticides

\section{Figures}


Fig. 1

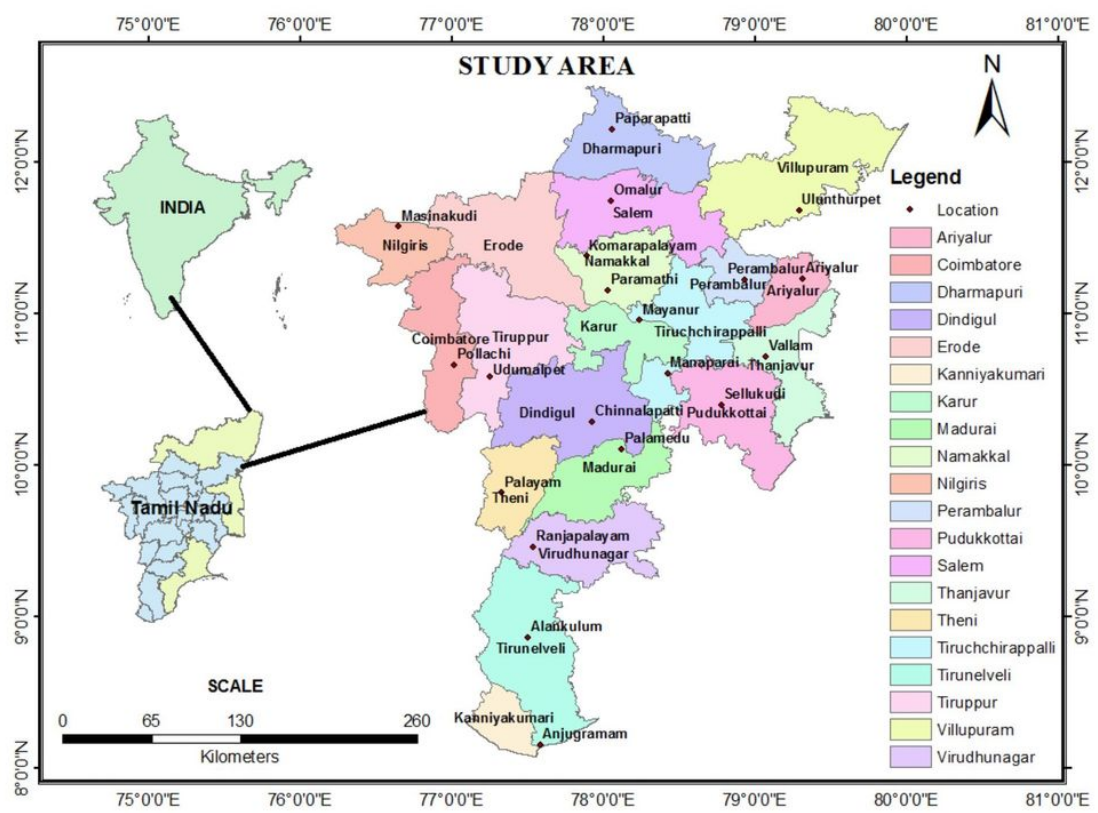

\section{Figure 1}

Image of Tamil Nadu geographical map showing collection sites of brinjal shoot and fruit borer, L. orbonalis in Tamil Nadu, South India 


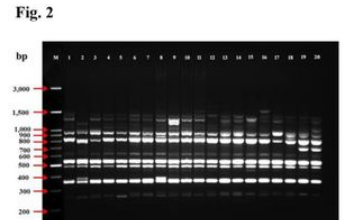

RAPD profile - OPA01

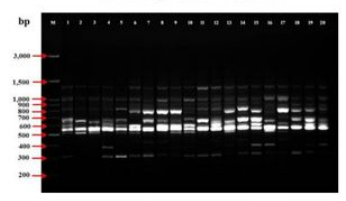

RAPD profile - OPA08

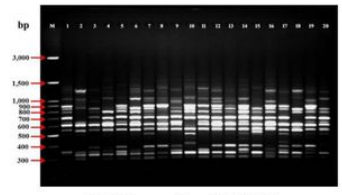

RAPD profile - OPG08

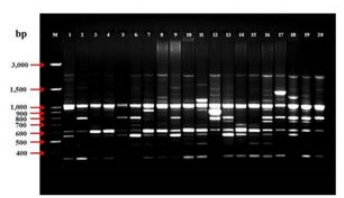

RAPD profile - OPS02

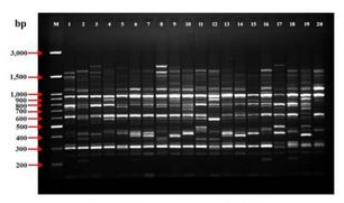

RAPD profile - OPS07

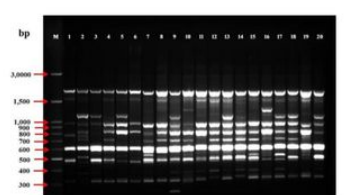

RAPD profile - OPA07

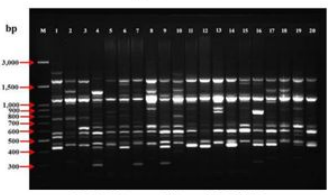

RAPD profile - OPG07

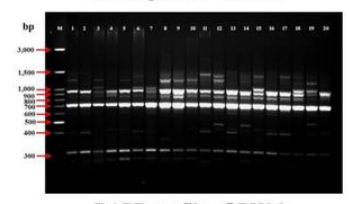

RAPD profile - OPK06

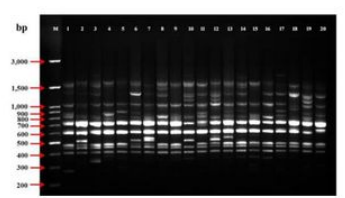

RAPD profile - OPS03

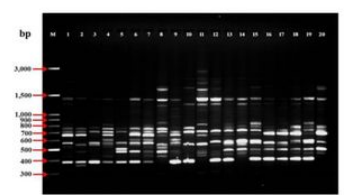

RAPD profile - OPS08

\section{Figure 2}

PCR-RAPD profile generated by ten selected random decamer primers with genomic DNA isolated from various populations of L. orbonalis. Lanes 1: MaduraiMDU; 2: Dindigul-DGL; 3: Theni-TNl; 4: Namakkal-NKL; 5: Erode-ERO; 6: Karur-KRR; 7: Salem-SLM; 8: Virudhunagar-VHN; 9: Tirunelveli-TVL; 10: DharmapuriDMI; 11: Kanyakumari-KKR; 12: Villupuram-VPM; 13: Trichy-TRY; 14: Pudukottai-PKl; 15: Tanjore-TNJ; 16: Ariyalur-ALR; 17: Perambalur-PMR; 18: CoimbatoreCBE; 19: Tirupur-TRR; 20: Ooty-OTY. M - 100 bp DNA ladder (GeneDireX, Bio-Helix Co Ltd, Taiwan) run as standard molecular weight marker 
Fig. 3

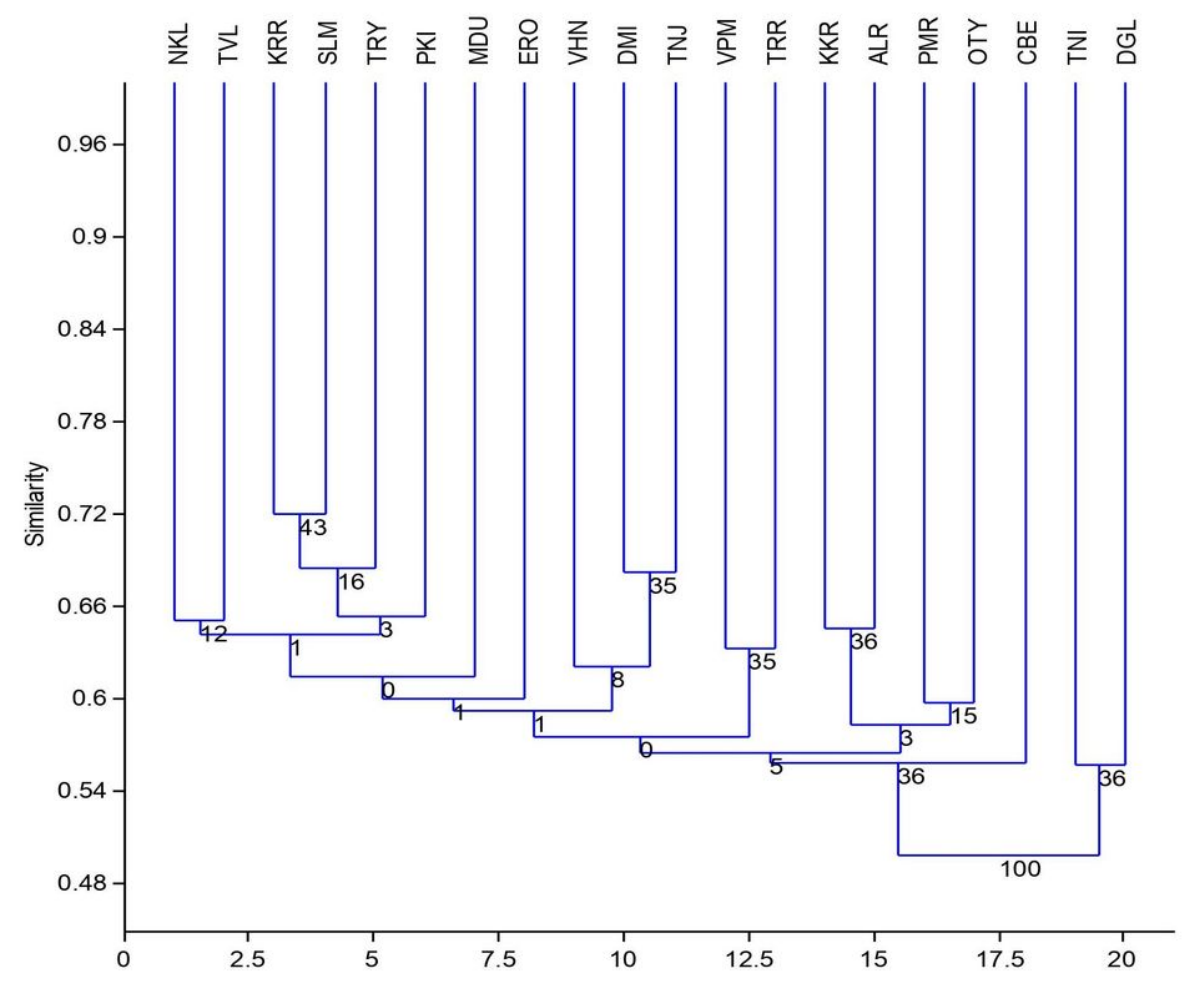

Figure 3

The dendrogram based UPGMA cluster analysis from the RAPD binary data showing the genetic variability among the populations of L. orbonalis 
Fig. 4

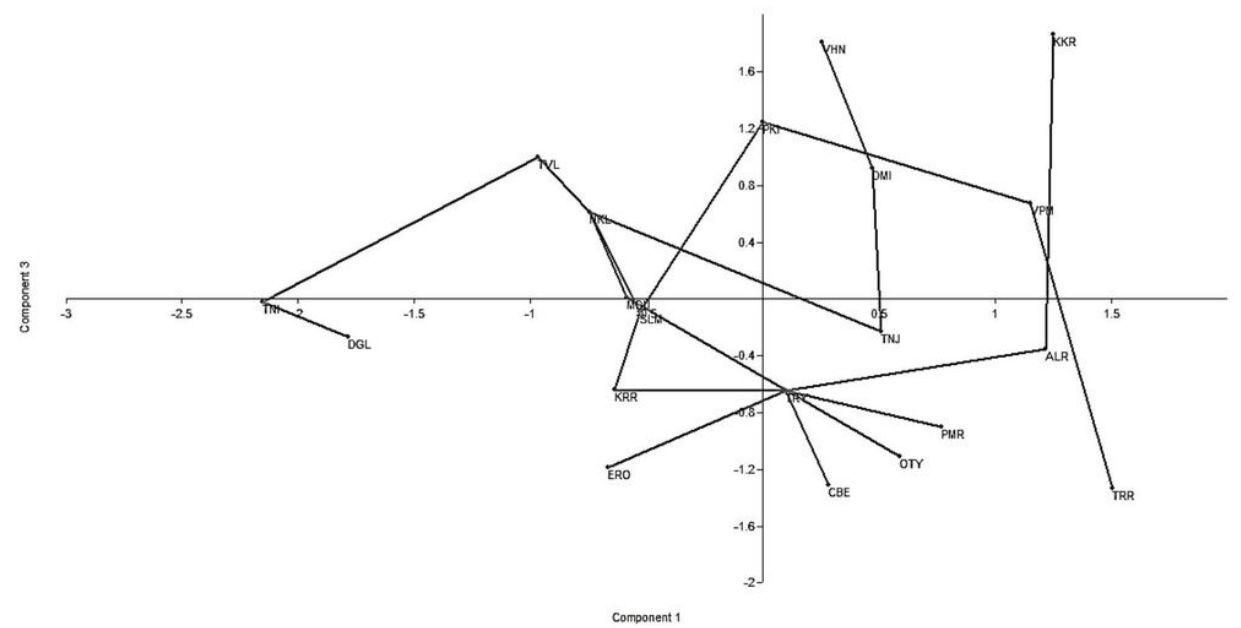

Figure 4

PCA scatter diagram analysis showing the distributions of $\mathrm{L}$. orbonalis populations

Page 15/21 
Fig. 5

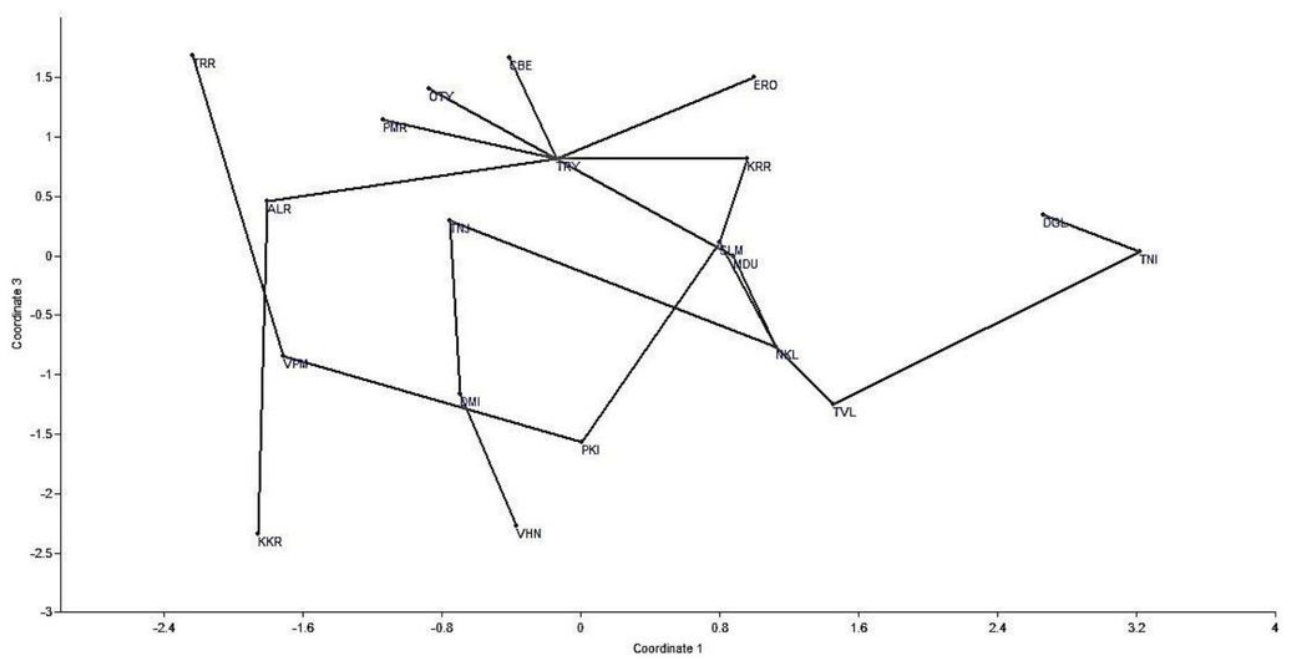

Figure 5

PCO scatter diagram analysis showing the distributions of L. orbonalis populations 
Fig. 6

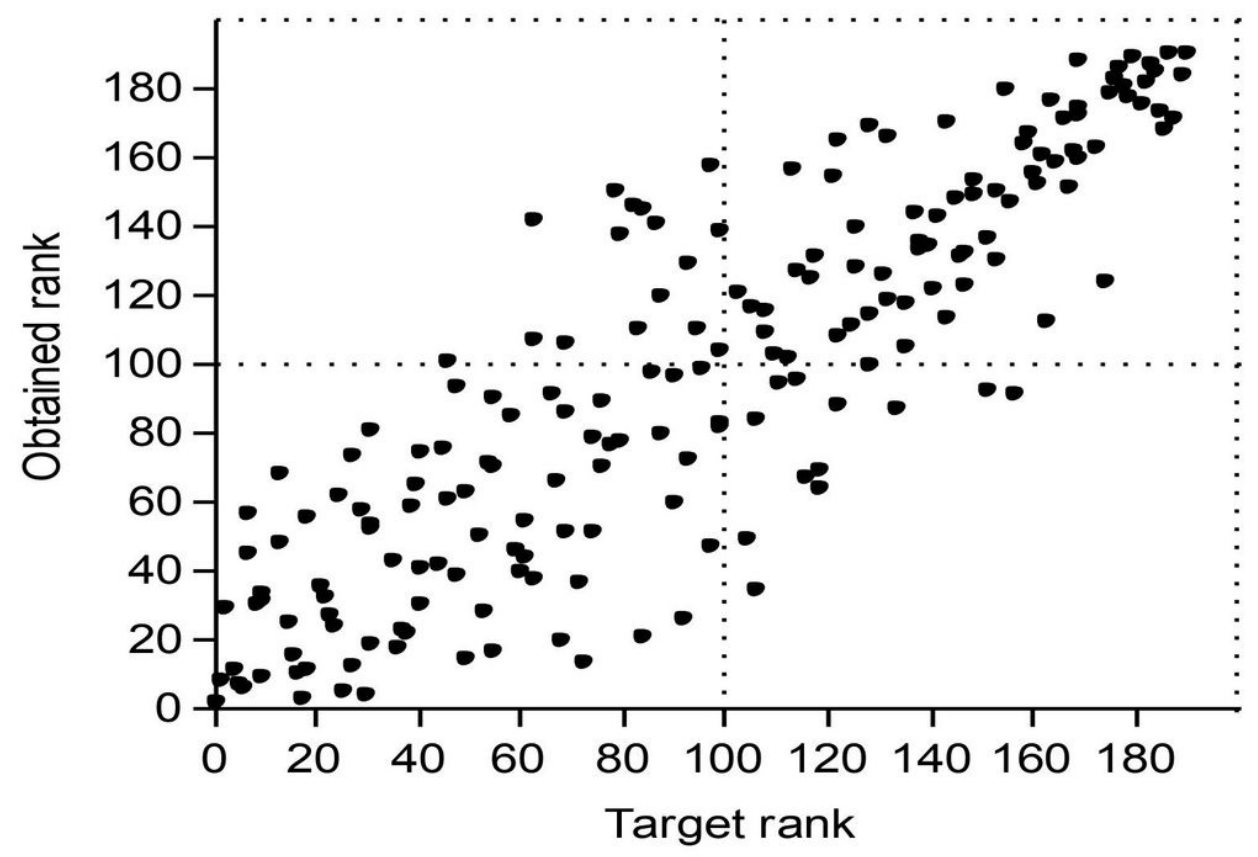

Figure 6

The nMDS Shephard's plot showing similar values in obtained rank and target rank 
Fig. 7
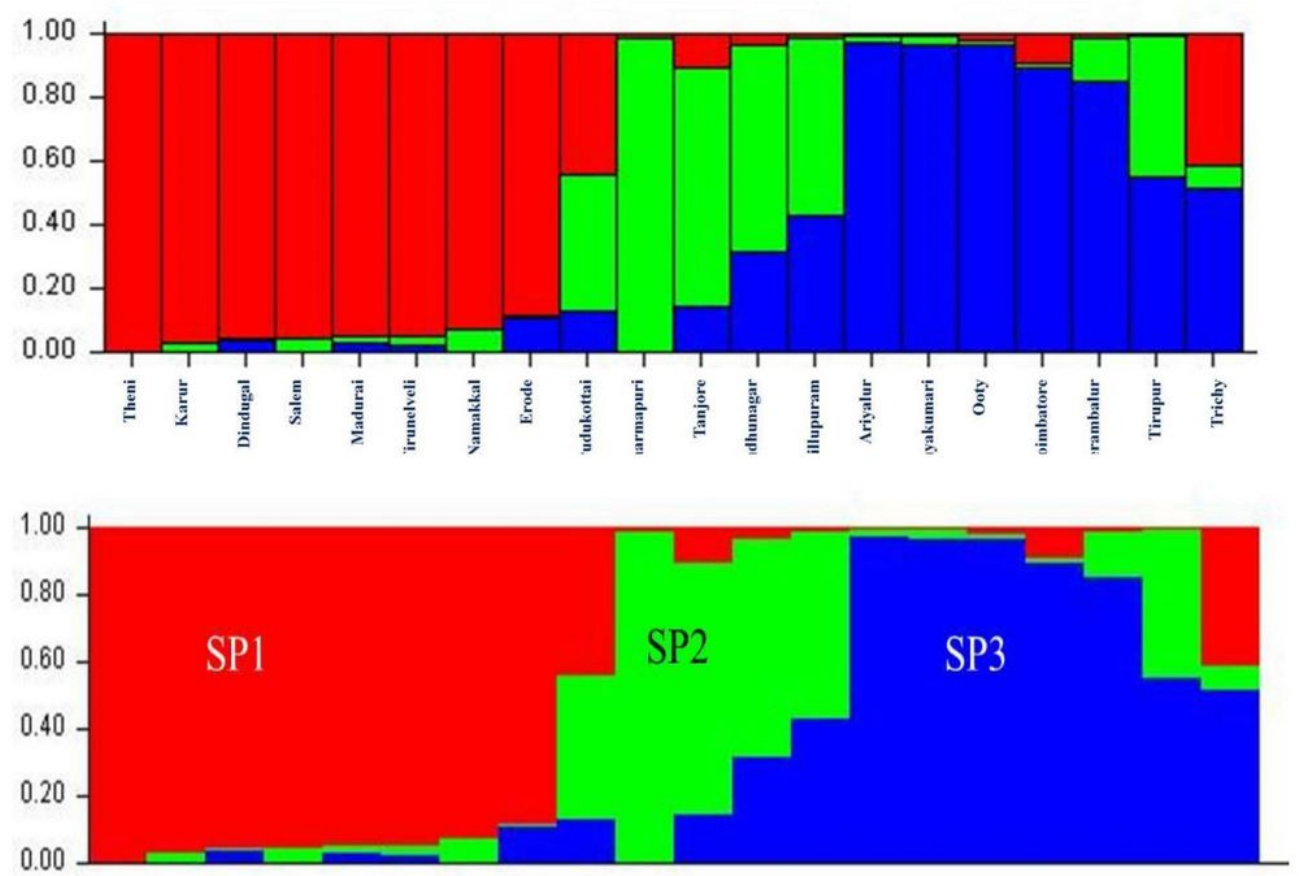

\section{Figure 7}

The subpopulations (SPs) showing admixture of alleles in genotypes of L. orbonalis populations based on structure analysis 
Fig. 8
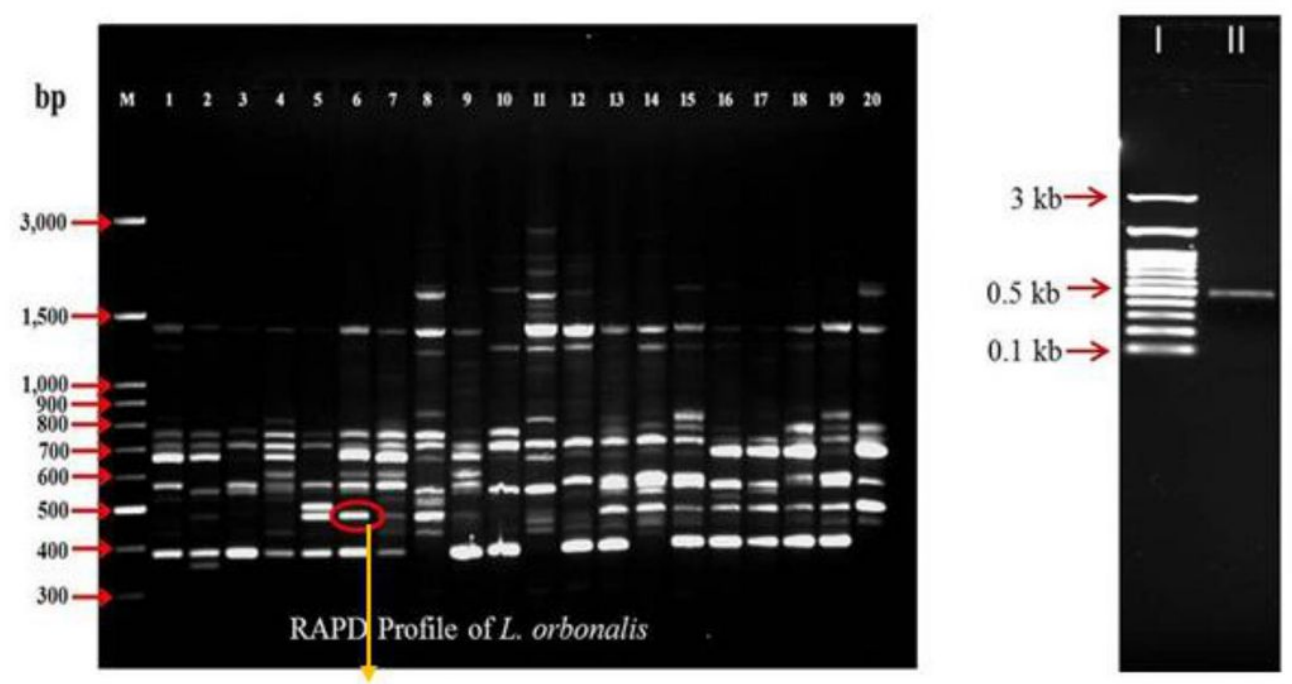

Trait specific marker

Figure 8

Electrophoretic profile (right) of trait specific locus extracted by gel purification from RAPD analysis. Lanes: I - 3 kb marker; II - $0.5 \mathrm{~kb}$ insert DNA (trait specific locus)

Fig. 9
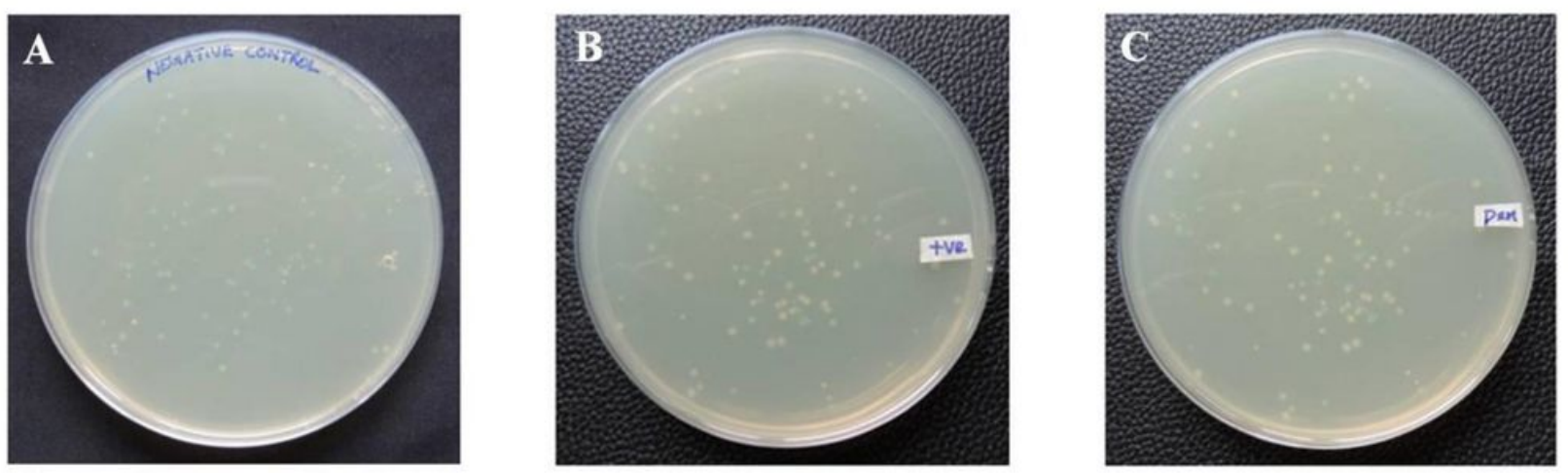
Fig. 10

\section{$>$ Insert DNA sequence (402 bp)}

ATTGTAATGTTGCTGTGATACGGCAGAGGCCAGTGGTTGTCCGGGAGCCAAATAT GCGTTGTCCCTAGTTGCTTTTCAGCTGATGGAACCCGTCATGAGAGTGGTGGAGG GTTTTAATTGTCTTGCTGACCTTTTAATTACTGGAATGTCCAGCCTCTAATTCCCT GATTCTTGTTTGGAACGCATGGCTTCTGTTCATAAGCTTCTTTAATATTGGTATTT TGCCTGACCTGCATGAGTAGTCCTTCATATGGCACGCGAGAGGATATGGCTCTCT GCGTAGGTGTGCGTGGCTCGTTGAGGTGCCTCTCTCTTCTCCTGTATAGCTGCTTC CCATTTCCCTAACTCGTTCTGGAACTTGTTGTGGCATATCAACAGGAAGACATAT TCTTGGGTTCTGCT

\section{Figure 10}

Nucleotide sequence of cloned RAPD fragment identified as SCAR marker 
Fig. 11

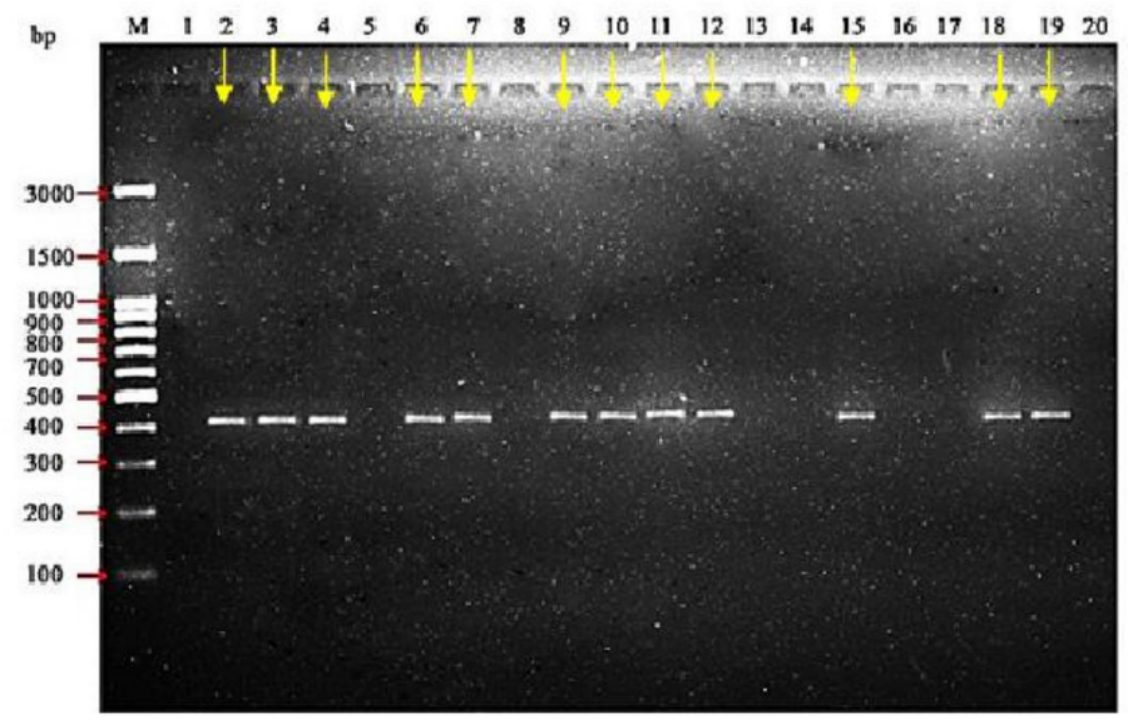

\begin{tabular}{cccccc}
\hline Lane No. & Location & Lane No. & Location & Lane No. & Location \\
\hline M & Marker & 7. & Salem & 14. & Pudukottai \\
1. & Madurai & 8. & Virudhunagar & 15. & Tanjore \\
2. & Dindugal & 9. & Trirunelveli & 16. & Ariyalur \\
3. & Theni & 10. & Dharmapuri & 17. & Perambalur \\
4. & Namakkal & 11. & Kanyakumari & 18. & Coimbatore \\
5. & Erode & 12. & Villupuram & 19. & Tirupur \\
6. & Karur & 13. & Trichy & 20. & Ooty \\
\hline
\end{tabular}

\section{Figure 11}

PCR analysis with genomic DNA of different populations of L. orbonalis using designed SCAR primers (Locations indicated in red colour \& marked with arrow at the top panel indicates populations positive for amplification with SCAR primers) 